\title{
PENGELOLAAN KEBUN KELAPASAWIT DALAM POLA KEMITRAAN INTI PLASMA PTPN II PRAFI DENGAN PETANI SUKU ARFAK DI MANOKWARI, PAPUA BARAT
}

MANAGEMENT OF PALM OIL FARM IN THE CORE PLASMA PTPN II PRAFI PARTNERSHIP PATTERN WITH ARFAK FARMERS IN MANOKWARI, PAPUA $B A R A T$

\author{
Amestina Matualage ${ }^{1}$, Sunarru Samsi Hariadi ${ }^{2}$, Paulus Wiryono ${ }^{2}$ \\ ${ }^{1}$ Mahasiswa Prodi S3 Penyuluhan dan Komunikasi Pembangunan, Sekolah Pascasarjana \\ Universitas Gadjah Mada, Yogyakarta \\ ${ }^{2}$ Staf pengajar Prodi S3 Penyuluhan dan Komunikasi Pembangunan, Sekolah Pascasarjana \\ Universitas Gadjah Mada, Yogyakarta \\ Email: ames n@yahoo.com
}

\begin{abstract}
Inti-Plasma partnership program (PIR) for oil palm in Manokwari has been going on since 1986. there's no one research about how they were managing their palm oil plantations through partnership program with PTPN II Prafi, although this data is needed for development planning in this area, especially for Arfak farmers and for palm oil company that still operate in this area. The aim of this research are to find out (1) how Arfak farmers manage their oil palm plantations and (2) what factors that influences this behavior. The research method uses survey method that involed 126 households of Afak farmers. The result show that in before the plantation have 10 years old, only 10 percent of Arfak farmer managed their oil palm plantation without used paid labor, a half of them was hired paid labor for harvest and the others contracted their plantation to non Arfak farmer (participant of Trans-PIR program from Java). After the plantation have 10 years old, most of Arfak farmers have been contracted their plantation to Java farmers and the others have been leave their plantation because unable to harvest. Age of farmer and their level of formal education have influenced their behavior to manage the palm oil plantation.
\end{abstract}

Keywords: Inti-Plasma partnership, Arfak farmer, oil palm plantation

\begin{abstract}
ABSTRAK
Program kemitraan Inti-Plasma (PIR) untuk kelapa sawit di Manokwari telah berlangsung sejak tahun 1986, namun belum ada penelitian tentang bagaimana mereka mengelola perkebunan kelapa sawit mereka melalui program kemitraan dengan PTPN II Prafi, padahal data ini diperlukan untuk perencanaan pembangunan di daerah ini, terutama untuk petani Arfak dan perusahaan kelapa sawit yang masih beroperasi di daerah ini. Tujuan dari penelitian ini adalah untuk mengetahui (1) bagaimana petani Arfak mengelola perkebunan kelapa sawit mereka dan (2) faktor-faktor apa yang mempengaruhi perilaku ini. Metode penelitian menggunakan metode survei yang melibatkan 126 rumah tangga petani Afak. Hasilnya menunjukkan bahwa sebelum tanaman berumur 10 tahun, sebagian petani menyewa tenaga kerja untuk mengelola kebunnya, sementara sebagian kecil mengontrakkannya kepada petani lain (peserta Trans-PIR program dari java). Setelah tanaman berumur 10 tahun, sebagian besar petani Arfak mengontrakkan kebun kelapa sawit mereka kepada petani jawa dan sebagian kecil petani Arfak telah meninggalkan kebun mereka karena mereka tidak dapat memanen. Bentuk pengelolaan ini dipengaruhi oleh umur dan tingkat pendidikan karena berkaitan dengan kekuatan fisik dan kemampuan berpikir petani untuk masa depannya.
\end{abstract}

Kata kunci: kemitraan inti plasma, petani Arfak, perkebunan kelapa sawit 


\section{PENDAHULUAN}

Pembangunan perkebunan di Indonesia sudah berlangsung sejak Repelita I (tahun 1973 - 1974) yang dilakukan dengan mengitegrasikan program transmigrasi dengan program Perkebunan Inti Rakyat (PIR). Saat itu pemerintah mulai membuka perkebuan di daerahdaerah tujuan Program Transmigrasi seperti Lampung dan Papua. Program ini bertujuan selain memeratakan jumlah penduduk, juga membuka kesempatan kerja bukan saja bagi peserta Program Transmigrasi, tetapi juga bagi penduduk lokal. Integrasi program transmigrasi dan perkebunan dikenal dengan istilah Trans-PIR (Transmigrasi - Perkebunan Inti Rakyat). Program ini merupakan program kemitraan antara Pemerintah, perusahaan perkebunan dan petani.

Kemitraan berdasarkan Peraturan Pemerintah no. 44 tahun 1997 tentang Kemitraan adalah kerjasama usaha antara Usaha Kecil dengan Usaha Menengah dan atau dengan Usaha Besar disertai pembinaan dan pengembangan oleh Usaha Menengah dan atau Usaha Besar dengan memperhatikan prinsip saling memerlukan, saling memperkuat dan saling menguntungkan. Definisi yang hampir sama adalah menurut Undang-undang no. 9 Tahun 1995 tentang usaha kecil yang diperbaharui dengan Undang-Undang Nomor 20 Tahun 2008 Tentang Usaha Mikro, Kecil dan Menengah Pasal 1 ayat 13 mengatakan bahwa yang dimaksud dengan kemitraan adalah kerjasama dalam keterkaitan usaha, baik langsung maupun tidak langsung, atas dasar prinsip saling memerlukan, mempercayai, memperkuat, dan menguntungkan yang melibatkan pelaku Usaha Mikro, Kecil, dan Menengah dengan Usaha Besar

Kabupaten Manokwari, khususnya Distrik Warmare, Prafi dan Masni merupakan daerah tujuan transmigrasi sejak tahun 1972 (daerah Warmare), 1982 (daerah Prafi) dan tahun 1986 (daerah Masni), sementara integrasi program transmigrasi dan perkebunan ditandai dengan dimulainya pembangunan kebun pada tahun 1983 dengan luasan kebun kelapa sawit sebesar $7.188,34$ hektar dan terdiri dari 14 afdeling tanaman (unit kerja), yaitu 8 afdeling plasma dan 6 afdeling inti. Peserta program Trans-PIR meliputi petani dari Jawa dan juga dari Papua (sekarang menjadi Papua dan Papua Barat).

Pembangunan perkebunan yang sudah berlangsung kurang lebih 30 tahun seharusnya sudah memperlihatkan hasil sesuai tujuan program, namun jika ditinjau dari hasil-hasil penelitian selama ini, belum ada hasil yang menunjukkan keberhasilan program seperti yang dikemukakan oleh Holle (2000) bahwa tingkat partisipasi petani peserta program PIR-Trans yang berasal dari Papua (khusus petani suku Arfak) sangat rendah, sehingga pendapatan yang diperoleh dari kebun kelapa sawit jauh lebih rendah dibanding petani lainnya, padahal secara ekonomi, dengan adanya program ini, pendapatan petani Arfak mengalami peningkatan walaupun jumlahnya lebih kecil dibanding pendapatan petani Jawa (Imbiri, 2010). Selain karena rendahnya partisipasi petani, juga karena keterikatan petani Arfak dengan budaya yang menyebabkan mereka tidak bisa mencurahkan waktu untuk mengelola kebun kelapa sawit disamping rendahnya kemampuan untuk melakukan budidaya kelapa sawit (Nauw, 2007). Dari sisi pemerintah, Obidzinski, Dermawan, and Hadianto (2014) menyimpulkan bahwa pemerintah harus mengubah asumsi mengenai hasil yang akan diperoleh setelah perkebunan kelapa sawit dibuka. Artinya bahwa asumsi hasil yang akan diperoleh melalui pola kemitraan kelapa sawit tidak bisa disama ratakan antara daerah yang satu dengan daerah yang lain. Temuan-temuan ini menunjukkan bahwa pembangunan perkebunan kelapa sawit melalui kemitraan inti plasma di Papua perlu diperbaiki. Rendahnya partisipasi petani Arfak dalam pengelolaan kebun kelapa sawit diduga disebabkan karena pengelolaan kebun yang tidak sesuai dengan pola kemitraan inti plasma, yang menekankan adanya partisipasi dari kedua pihak yang bermitra serta keuntungan yang sama bagi kedua pihak. Untuk mengetahui bagaimana pengelolaan kebun kelapa sawit yang dipraktekkan oleh petani Arfak peserta program Trans - PIR, maka perlu dilakukan penelitian dengan judul Pengelolaan Kebun Kelapa Sawit dalam Pola Kemitraan Inti Plasma PTPN II Prafi dengan Petani Suku Arfak di Manokwari, Papua Barat.

Penelitian yang telah dilakukan terhadap petani Arfak peserta program ini juga telah dilakukan oleh Sumule pada tahun 1994, Holle pada tahun 2000, Nauw pada tahun 2006 
dan Imbiri pada tahun 2010 namun penelitian-penelitian tersebut menemukan bahwa petani Arfak peserta program Trans-PIR belum berhasil jika dibandingkan dengan peserta program Trans-PIR dari daerah lain, seperti dari pulau Jawa, padahal perlakuan yang diberikan kepada petani Arfak dan yang lainnya sama. Hal ini menarik untuk dikaji, apa yang melatarbelakangi petani Arfak sehingga mereka belum berhasil dalam mengelola kelapa sawit melalui program kemitraan Trans-PIR ini.

Berdasarkan hasil-hasil penelitian tentang pola kemitraan, terbukti bahwa pola kemitraan antara petani dengan perusahaan/lembaga banyak yang berhasil walaupun masih ada yang belum sepenuhnya berhasil seperti pola kemitraan antara petani padi dengan PT.EFarm Bisnis Indonesia yang berhasil meningkatkan pendapatan petani namun, peningkatan pendapatan tersebut tidak atau belum memperlihatkan kondisi yang diharapkan petani dalam melakukan kemitraan, seperti terjadinya efisiensi, produktivitas dan harga jual yang tinggi, serta bargaining position petani yang kuat (Rochdiani \& Suranta, 2007). Pola kemitraan yang memberikan manfaat kepada pesertanya terlihat pada hasil penelitian yang dilakukan oleh Purnaningsih and Sugihen (2008) serta R.Ratnasari, W.Sarengat, and A.Setiadi (2015) yang meneliti tentang pola kemitraan yang berhasil meningkatkan pendapatan petani pesertanya, begitu juga dengan pola kemitraan yang dilakukan antara petani cabai dengan koperasi yang mampu meningkatkan pendapatan petani secara signifikan (Rudiyanto, 2014). Program kemitraan tersebut bisa memberi manfaat kepada petani karena persepsi yang positif dari petani plasma peserta program kemitraan seperti yang dikemukakan oleh Suryana (2009). Hal ini menggambarkan bahwa petani masih membutuhkan dukungan kemitraan dari pihak lain untuk meningkatkan pendapatan mereka. Keuntungan lain dari program kemitraan dengan petani adalah apabila terjadi hal-hal yang tidak diinginkan seperti kerugian, petani tidak menganggung sendiri seperti yang diteliti oleh Suharno, A.D, and Barbara (2015).

Pola kemitraan inti plasma, adalah pola kemitraan dengan perusahaan/pemodal sebagai inti sementara petani sebagai plasma. Beberapa hasil penelitian menunjukkan bahwa pola kemitraan inti plasma masih menghadapi kendala dalam pelaksanaannya, misalnya yang dikemukakan oleh (I Made Gannal Dwi Saputra, I G A A Lies Anggreni, \& Dharma, 2017), namun, ada juga pola kemitraan PIR Trans yang berhasil meningkatkan pendapatan petani plasma dan kedua pihak berhasil melaksanakan kewajibannya sesuai kesepakatan pada awal kontrak, seperti hasil penelitian Nasution (2016) terhadap petani plasma dan PT Agrowiyana di Kabupaten Tanjung Jabung Barat.

Perkebunan kelapa sawit sebagai salah satu bentuk pertanian komersial merupakan suatu hal yang baru bagi petani Arfak yang masih tradisional dan hingga kini masih melakukan teknik ladang berpindah dengan komoditi lokal seperti ubi jalar,Matualage (2011), U.Yuminarti, Darwanto, Jamhari, and Subejo (2018) dan Yuminarti, Darwanto, Jamhari, and Subejo (2018). Sebagai salah satu komoditi dalam pertanian komersial, usaha perkebunan kelapa sawit tidak bisa lepas dari masalah komunikasi, Subejo et al. (2018) dan Christian and Subejo (2018). Kemitraan adalah salah satu bentuk komunikasi yang dianggap bisa menjembatani petani Arfak yang masih tradisional dengan perusahaan perkebunan kelapa sawit yang sudah mempraktekkan pertanian komersial.

Penelitian tentang kemitraan sudah banyak dilakukan, dan hasilnya menunjukkan bahwa program kemitraan merupakan program yang menguntungkan petani. Walaupun demikian masih banyak petani yang belum menjadi mitra perusahaan pertanian, khususnya di daerah Papua/Papua Barat. Oleh karena itu diperlukan penelitian terhadap petani peserta program kemitraan di Papua/Papua Barat, sehingga dapat diketahui kendala yang dihadapi petani maupun perusahaan mitra dan pada akhirnya dapat dicari jalan keluar untuk menghadapi kendala-kendala tersebut di masa mendatang.

Berdasarkan hal tersebut, maka tujuan dari penelitian ini adalah mengetahui bagaimana pengelolaan kebun kelapa sawit yang dilakukan oleh petani Arfak peserta program Trans - PIR di Kabupaten Manokwari dan faktor apa saja yang mempengaruhinya. Diharapkan melalui penelitian ini dapat ditemukan pola-pola pengelolaan kebun kelapa sawit sebelum tanaman berumur 10 tahun dan setelah tanaman berumur 10 tahun sehingga dapat digunakan sebagai 
bahan perencanaan bagi pembangunan perkebunan berikutnya.

\section{METODE PENELITIAN}

Metode penelitian yang digunakan dalam penelitian ini adalah metode kuantitatif dengan metode pengambilan data yang digunakan adalah survey dengan teknik studi kasus. Sebagai kasus dalam penelitian ini adalah petani Suku Arfak di Kabupaten Manokwari, Provinsi Papua Barat. Survey dilakukan terhadap 3 distrik yang diambil secara purposif dengan pertimbangan bahwa ketiga distrik tersebut merupakan distrik tujuan program Trans - PIR. Dari ketiga distrik tersebut, diambil masing-masing 1 desa yang banyak dihuni oleh petani Arfak. Dari 3 desa terpilih, diambil 126 responden secara acak dari daftar petani peserta program Trans -PIR.

Data yang dikumpulkan dalam penelitian ini adalah data primer dan data sekunder. Data primer diperoleh dari hasil wawancara dengan responden dengan menggunakan kuesioner dan wawancara mendalam serta observasi di lapangan, sementara data sekunder diperoleh dari penelusuran pustaka dan dari instansi terkait.

Variabel yang diteliti dalam penelitian ini adalah bentuk pengelolaan dan karakteristik petani yang meliputi umur dan tingkat pendidikan. Analisis data yang digunakan untuk menjawab tujuan penelitian adalah dengan menggunakan statistik deskriptif yang digambarkan dengan diagram pie dan crosstabulation untuk mengetahui hubungan variabel dependen dan independen.

\section{HASIL DAN PEMBAHASAN}

Karakeristik petani Arfak yang diteliti meliputi umur dan tingkat pendidikan. Hasil penelitian tentang umur dan tingkat pendidikan responden disajikan pada tabel berikut ini:

Tabel 1. Sebaran responden berdasar-kan kelompok umur

\begin{tabular}{ccc}
\hline Kelompok Umur & Jumlah $(\mathrm{KK})$ & Nisbah (\%) \\
\hline$<34$ & 1 & 0,8 \\
$35-54$ & 81 & 64,3 \\
$>54$ & 44 & 34,9 \\
\hline Total & 126 & 100,0 \\
\hline
\end{tabular}

Sumber: data primer, 2017

Berdasarkan Tabel 1, terlihat bahwa petani Suku Arfak yang terlibat dalam program Trans - PIR sebagian besar berada pada kelompok umur 35 sampai 54 tahun, yang berarti sebagian besar berada pada usia produktif. Walaupun demikian, petani yang berada pada kelompok umur tidak produktif (lebih dari 54 tahun) cukup banyak (34,9\%). Banyaknya petani yang berusia lanjut ini berpengaruh pada pola pengelolaan kebun kelapa sawit.

Petani suku Arfak yang berusia produktif yang menjadi peserta program PIR ini disebabkan karena sebagian dari mereka adalah petani yang orang tuanya yang menjadi peserta program PIR pada tahun 1980an sudah meninggal dan mewariskan kebun kelapa sawit yang dimiliki kepada anak mereka untuk melanjutkan kegiatan pengelolaan kebun kelapa sawit. Anak-anak mereka dipercayakan untuk mengelola kebun kelapa sawit karena dianggap mampu mengelola dan selama orang tua mereka hidup, mereka turut serta membantu orang tua mereka mengelola kebun kelapa sawit. Hasil penelitian tentang tingkat pendidikan petani disajikan pada Tabel 2 berikut ini: 
Tabel 2. Sebaran responden berdasarkan Tingkat Pendidikan

\begin{tabular}{ccc}
\hline Tingkat Pendidikan & Jumlah (Jiwa) & Nisbah (\%) \\
\hline Tidak sekolah & 61 & 48,4 \\
SD & 54 & 42,9 \\
SMP & 7 & 5,6 \\
SMA & 1 & 0,8 \\
PT & 3 & 2,4 \\
\hline Jumlah & 126 & 100,00
\end{tabular}

Tabel 2 menunjukkan bahwa walaupun sangat tipis bedanya, petani yang pernah mengenyam pendidikan formal lebih banyak prosentasenya $(51,6 \%)$ dibanding petani yang tidak pernah mengenyam pendidikan formal $(48,4 \%)$. Hal ini disebabkan karena petani peserta program Trans - PIR berasal dari daerah yang tidak memiliki sekolah sebelum mereka mengikuti program Trans - PIR (daerah pedalaman di pegunungan Arfak).

\section{Bentuk Pengelolaan Usahatani Kelapa Sawit}

Berdasarkan aturan pola inti plasma, kebun plasma pada awalnya dikelola oleh perusahaan perkebunan besar, mulai dari pembibitan, penanaman di lahan dan pemeliharaan. Setelah Kebun kelapa sawit berusia 4 tahun, kebun siap untuk diserahkan kepada petani. Setelah diserahkan kepada petani, semua kegiatan pemeliharaan menjadi tanggung jawab petani. Pengelolaan kebun kelapa sawit yang dipraktekkan oleh petani Arfak, dibagi menjadi 2 bagian, yaitu ketika kelapa sawit berumur hingga 10 tahun setelah diserahkan kepada petani dan setelah berumur lebih dari 10 tahun setelah diserahkan. Bentuk pengelolaan kebun kelapa sawit ketika kelapa sawit berumur 0 hingga 10 tahun setelah diserahkan disajikan pada Diagram PIE berikut ini:

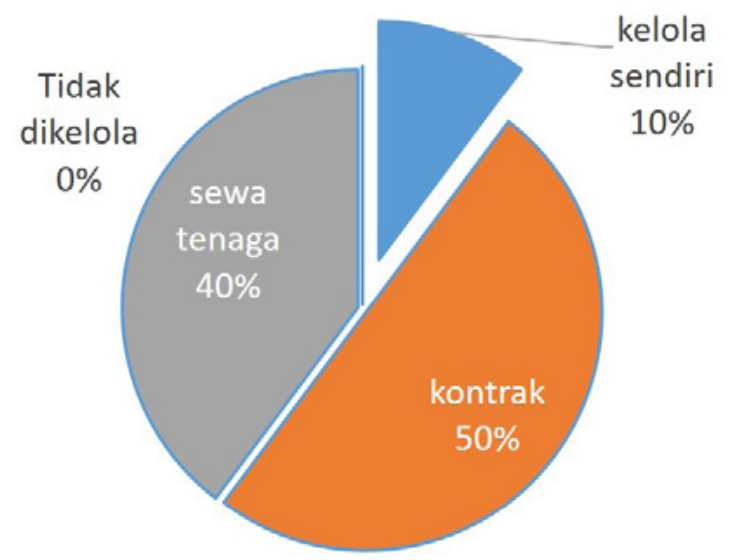

Gambar 1. Bentuk Pengelolaan Kebun Kelapa Sawit oleh petani Suku Arfak pada saat umur kelapa sawit kurang dari 10 setelah diserahkan kepada petani

(Sumber: Data Primer, 2017)

Gambar 1 menunjukkan bahwa bentuk pengelolaan kebun kelapa sawit yang dilakukan oleh petani Suku Arfak terdiri dari 3 jenis, yaitu dikelola sendiri, menyewa tenaga kerja dan mengontrakkan kebun kelapa sawit kepada petani lain. Gambar 1 juga menunjukkan bahwa separuh (50\%) petani Arfak mengontrakkan lahannya kepada petani lain (petani asal Suku Jawa), sementara petani yang mengelola kebunnya sendiri hanya $10 \%$ atau 13 orang serta prosentase petani yang menyewa tenaga kerja cukup banyak (40\%). Hal ini disebabkan karena mereka merasa sulit untuk memanen kelapa sawit yang tingginya mencapai 8 sampai 10 meter dengan menggunakan egrek, selain itu mereka tidak mempunyai cukup ketrampilan untuk mengelola kebun kelapa sawit meskipun pihak perusahaan telah melakukan penyuluhan tentang budidaya 
kelapa namun petani Arfak tidak mengikutinya karena frekuensi mereka kembali ke kampung lama yang tinggi untuk menyelesaikan permasalahan adat ataupun menghadiri upacara adat. Tingginya frekuensi petani Arfak ke kampung asal mereka selain karena keperluan adat, juga karena petani Arfak masih terikat dengan "budaya balas dendam". Budaya balas dendam artinya petani Arfak mempunyai kebiasaan membalas perbuatan orang lain (sesama suku Arfak) di masa yang lalu. Hal ini disebabkan oleh adanya prinsip bahwa "makanan kalo masih panas tidak boleh langsung dimakan, tetapi harus menunggu hingga makanan tersebut dingin" (Nauw, 2007). Prinsip ini mengandung arti bahwa jika seseorang membuat suatu kesalahan kepada orang lain, maka perbuatan itu akan dibalas oleh korban di masa yang akan datang. Pembalasan dendam di kalangan Suku Ardak dilakukan dengan mengupah seseorang yang mempunya kekuatan supra natural/magis (biasa disebut sebagai "Suanggi") untuk membunuh korbannya. Sasaran balas dendam biasanya tidak saja pada pelaku utama dari perselisihan di masa lalu, tetapi bisa merambat ke keluarga besar, sehingga petani Suku Arfak selalu merasa ketakutan jika melakukan aktivitas seorang diri seperti di kebun kelapa sawit. Setelah tanaman kelapa sawit berumur 10 tahun, bentuk pengelolaan kebun seperti digambarkan pada Gambar 2.

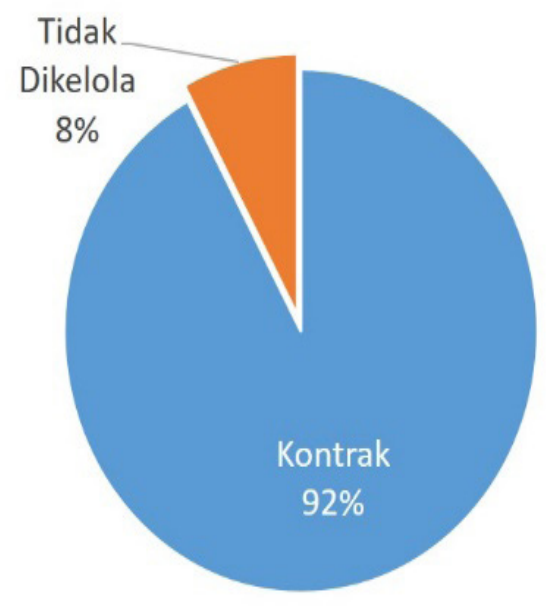

Gambar 2. Bentuk Pengelolaan Kebun Kelapa Sawit oleh petani Suku Arfak pada saat umur kelapa sawit lebih dari 10 setelah diserahkan kepada petani

(Sumber: Data Primer, 2017)

Gambar 2 menunjukkan bahwa sebagian besar petani (92\%) mengontrakkan lahannya kepada petani asal Suku Jawa, sementara $8 \%$ petani membiarkan kebun kelapa sawitnya tidak dikelola. Jika dibandingkan Gambar 1 dan Gambar 2, pada saat kebun masih berusia muda (kurang dari 10 tahun), bentuk pengelolaan kebun pada waktu tanaman berusia muda dan ketika tanaman sudah berusia diatas 10 tahun berbeda. Pada saat kelapa sawit masih berusia muda, terdapat petani menyewa tenaga kerja untuk mengerjakan kebun kelapa sawitnya, baik untuk membersihkan piringan pohon, maupun memanen TBS dan membawanya ke perusahaan, dan semua petani mengelola kebun kelapa sawitnya. Tapi setelah kelapa sawit berumur lebih dari 10 tahun, bentuk pengelolaan mengerucut menjadi 2, yaitu mengontrakkannya (92\%) dan membiarkan kebun kelapa sawitnya tanpa pengelolaan sama sekali (8\%)

Sistem kontrak yang diterapkan merupakan sistem kontrak yang tidak tertulis, artinya pengontrak dan pemilik kebun hanya membuat kesepakatan secara lisan tentang kompensasi kontrak, lama kontrak dan besarnya nilai kontrak. Sistem kontrak ini bukanlah sistem kontrak antara pengusaha dengn petani seperti yang ditetapkan oleh pemerintah dalam UU no.20 Tahun 2008 Tentang Usaha Mikro, Kecil, dan Menengah (Anonim, 2008), tetapi kontrak yang dilakukan secara perorangan.

Sistem kontrak usaha pertanian dalam contract farming (Rustiani, Sjaifudian, \& Gunawan, 1997) juga berbeda dengan sistem kontrak yang dipraktekkan petani Arfak dengan petani Jawa 
karena tidak ada misi pemberdayaan dalam kontrak ini, yang ada hanya menguntungkan pihak pengontrak. Sistem kontrak yang diterapkan antara petani Arfak dan pengontrak ini disetujui oleh petani Arfak karena secara umum, petani Papua mempunyai persepsi yang penting kebutuhan hidup sudah terpenuhi, sudah cukup bagi mereka, dan tidak ingin berpikir yang sulit tentang hidup (Turua, Hadi, Juanda, \& Murniningtyas, 2014). Hal ini membuka kesempatan bagi pengontrak/pihak lain di luar Suku Arfak untuk mengambil keuntungan melalui pengelolaan kebun kelapa sawit. Pengontrak memanfaatkan persepsi petani Arfak yang sederhana dan tidak mau repot memikirkan bagaimana mengelola kebun kelapa sawit.

Uji Lanjutan Faktor-Faktor yang Mempengaruhi Pengelolaan Kebun Kelapa Sawit

a. Hubungan Umur dan Tingkat Pendidikan terhadap bentuk pengelolaan kebun kelapa sawit sebelum tanaman berumur 10 tahun

Hubungan antara umur dan pemilihan bentuk pengelolaan diuji dengan menggunakan uji Crosstabulation. Hasil pengujian adalah sebagai berikut:

Tabel 3. Crosstabulation antara Umur dan Bentuk Pengelolaan Kebun Kelapa Sawit Sebelum Tanaman Berumur 10 Tahun

\begin{tabular}{|c|c|c|c|c|c|c|c|c|}
\hline \multirow{3}{*}{ Umur } & \multicolumn{6}{|c|}{ Bentuk Pengelolaan } & \multirow{2}{*}{\multicolumn{2}{|c|}{ Total }} \\
\hline & \multicolumn{2}{|c|}{ Kontrak } & \multicolumn{2}{|c|}{ Sewa Tenaga } & \multicolumn{2}{|c|}{ Kelola sendiri } & & \\
\hline & $\begin{array}{l}\text { Jumlah } \\
\text { (Jiwa) }\end{array}$ & $\begin{array}{c}\text { Nisbah } \\
(\%)\end{array}$ & $\begin{array}{c}\text { Jumlah } \\
\text { (Jiwa) }\end{array}$ & $\begin{array}{c}\text { Nisbah } \\
(\%)\end{array}$ & $\begin{array}{l}\text { Jumlah } \\
\text { (Jiwa) }\end{array}$ & $\begin{array}{c}\text { Nisbah } \\
(\%)\end{array}$ & $\begin{array}{c}\text { Jumlah } \\
\text { (Jiwa) }\end{array}$ & $\begin{array}{c}\text { Nisbah } \\
(\%)\end{array}$ \\
\hline$<35$ Tahun & 0 & 0,00 & 1 & 1,85 & 0 & 0,00 & 1 & 0,79 \\
\hline 35 - 54 Tahun & 38 & 64,41 & 36 & 66,67 & 7 & 53,85 & 81 & 64,29 \\
\hline$>54$ Tahun & 21 & 35,59 & 17 & 31,48 & 6 & 46,15 & 44 & 34,92 \\
\hline Total & 59 & 100,00 & 54 & 100,00 & 13 & 100,00 & 126 & 100,00 \\
\hline
\end{tabular}

Sumber: Data Primer, 2017, diolah

Tabel 3 menunjukkan bahwa sistem kontrak bentuk pengelolaan kontrak merupakan bentuk pengelolaan yang paling banyak dipilih oleh petani dari 2 kelompok umur, baik kelompok umur 35-54 tahun tapi juga oleh petani yang berusia lanjut, sementara untuk petani yang relatif masih muda (berusia kurang dari 34 tahun) yang seharusnya bisa mengerjakan sendiri lahan kelapa sawitnya malah memilih menyewa tenaga kerja untuk mengelolanya. Hubungan antara bentuk pengelolaan kebun kelapa sawit dengan tingkat pendidikan petani Suku Arfak disajikan pada Tabel 4 dan hasil analisis crosstabulation sebagai berikut:

Tabel 4. Crosstabulation antara Tingkat Pendidikan dan Bentuk Pengelolaan Kebun Kelapa Sawit Sebelum Tanaman Berumur 10 Tahun

\begin{tabular}{|c|c|c|c|c|c|c|c|c|}
\hline \multirow{3}{*}{ Tingkat Pendidikan } & \multicolumn{6}{|c|}{ Bentuk Pengelolaan } & \multirow{2}{*}{\multicolumn{2}{|c|}{ Total }} \\
\hline & \multicolumn{2}{|c|}{ Kontrak } & \multicolumn{2}{|c|}{ Sewa Tenaga } & \multicolumn{2}{|c|}{ Kelola sendiri } & & \\
\hline & $\begin{array}{l}\text { Jumlah } \\
\text { (Jiwa) }\end{array}$ & $\begin{array}{c}\text { Nisbah } \\
(\%)\end{array}$ & $\begin{array}{c}\text { Jumlah } \\
\text { (Jiwa) }\end{array}$ & $\begin{array}{c}\text { Nisbah } \\
(\%)\end{array}$ & $\begin{array}{c}\text { Jumlah } \\
\text { (Jiwa) }\end{array}$ & $\begin{array}{c}\text { Nisbah } \\
(\%)\end{array}$ & $\begin{array}{c}\text { Jumlah } \\
\text { (Jiwa) }\end{array}$ & $\begin{array}{c}\text { Nisbah } \\
(\%)\end{array}$ \\
\hline Tidak Sekolah & 33 & 55,93 & 21 & 38,89 & 7 & 53,85 & 61 & 48,41 \\
\hline $\mathrm{SD}$ & 22 & 37,29 & 27 & 50,00 & 5 & 38,46 & 54 & 42,86 \\
\hline SMP & 4 & 6,78 & 3 & 5,56 & 0 & 0,00 & 7 & 5,56 \\
\hline SMA & 0 & 0,00 & 1 & 1,85 & 0 & 0,00 & 1 & 0,79 \\
\hline Perguruan Tinggi & 0 & 0,00 & 2 & 3,70 & 1 & 7,69 & 3 & 2,38 \\
\hline Total & 59 & 100,00 & 54 & 100 & 13 & 100 & 126 & 100,00 \\
\hline
\end{tabular}

Sumber: Data Primer, 2017

Tabel 4 menunjukkan bahwa pemilihan bentuk pengelolaan kebun kelapa sawit secara kontrak, paling banyak dilakukan oleh petani Arfak yang tidak pernah mengenyam 
pendidikan (55,93\%), begitu juga dengan pengelolaan kebun yang dilakukan sendiri, sebagian besar dilakukan oleh petani yang tidak bersekolah (53,85\%), sementara petani Arfak yang mempunyai tingkat pendidikan yang tinggi (perguruan tinggi) sebagian besar lebih memilih untuk menyewakan kebunnya dan sebagian kecil mengelolanya sendiri. Hal ini dilakukan karena belum mempunyai pekerjaan tetap.

Hasil uji korelasi Spearman tentang hubungan antara variabel umur dan tingkat pendidikan terhadap pemilihan bentuk pengelolaan kebun kelapa sawit disajikan pada Tabel 6 berikut ini:

Tabel 6. Uji Statistik Spearman Faktor-faktor yang mempengaruhi pengambilan keputusan dalam pemilihan usaha kelapa sawit sebelum tanaman berumur 10 tahun

\begin{tabular}{lcc}
\hline & Korelasi Spearman & Tingkat signifikansi \\
\hline Usia & 0,006 & 0,950 \\
Pendidikan & $-0,030$ & 0,735 \\
\hline
\end{tabular}

Tabel 6 menunjukkan bahwa baik umur maupun pendidikan tidak signifikan mempengaruhi keputusan petani memilih bentuk pengelolaan yang ditunjukkan dengan tingkat signifikansi yang lebih dari 0,005 . Hal ini berarti bahwa semakin tinggi tingkat pendidikan seorang petani Arfak,ataupun semakin bertambah usia seorang petani, maka ada kecenderungan memilih bentuk pengelolaan tertentu karena pemilihan bentuk pengelolaan lebih disebabkan karena budidaya kelapa sawit adalah suatu inovasi yang asing bagi petani Arfak, dimana sistem budidayanya sangat berbeda dengan kebiasaan mereka dalam bercocok tanam yang masih menganut sistem ladang berpindah (U.Yuminarti et al., 2018; Yuminarti et al., 2018).

b. Hubungan Umur dan Tingkat Pendidikan terhadap bentuk pengelolaan kebun kelapa sawit sebelum tanaman berumur 10 tahun

Setelah tanaman berumur lebih dari 10 tahun, bentuk pengelolaan kebun berubah seperti yang sudah dijelaskan sebelumnya. Untuk mengetahui faktor penyebab pemilihan model pengelolaan setelah tanaman berumur lebih dari 10 tahun, digunakan analisis crosstabulation sebagai berikut:

Tabel 7. Crosstabulation antara Umur dan Bentuk Pengelolaan Kebun Kelapa Sawit Setelah Tanaman Berumur Lebih dari 10 Tahun

\begin{tabular}{|c|c|c|c|c|c|c|}
\hline \multirow{3}{*}{ Umur } & \multicolumn{4}{|c|}{ Bentuk Pengelolaan } & \multirow{2}{*}{\multicolumn{2}{|c|}{ Total }} \\
\hline & \multicolumn{2}{|c|}{ Tidak dikelola } & \multicolumn{2}{|c|}{ Kontrak } & & \\
\hline & $\begin{array}{c}\text { Jumlah } \\
\text { (Jiwa) }\end{array}$ & Nisbah (\%) & $\begin{array}{c}\text { Jumlah } \\
\text { (Jiwa) }\end{array}$ & Nisbah (\%) & $\begin{array}{c}\text { Jumlah } \\
\text { (Jiwa) }\end{array}$ & Nisbah (\%) \\
\hline$<35$ Tahun & 0 & 0,00 & 1 & 0,86 & 1 & 0,79 \\
\hline $\begin{array}{l}35-54 \text { Tahun } \\
>54 \text { Tahun }\end{array}$ & $\begin{array}{r}0 \\
10\end{array}$ & $\begin{array}{r}0,00 \\
100,00\end{array}$ & $\begin{array}{l}81 \\
34\end{array}$ & $\begin{array}{l}69,83 \\
29,31\end{array}$ & $\begin{array}{l}81 \\
44\end{array}$ & $\begin{array}{l}64,29 \\
34,92\end{array}$ \\
\hline Total & 10 & 100,00 & 116 & 100,00 & 126 & 100,00 \\
\hline
\end{tabular}

Tabel 7 menunjukkan bahwa dari 3 bentuk pengelolaan yang dilakukan ketika tanaman berusia kurang dari 10 tahun, menjadi 2 bentuk pengelolaan, artinya tidak ada satupun petani memilih untuk menyewa tenaga kerja untuk mengerjakan kebun kelapa sawitnya. Tabel 5 juga menunjukkan bahwa hanya petani yang berusia lanjut ( $10 \%$ dari total petani berusia lanjut) yang memilih untuk membiarkan kebun kelapa sawitnya tidak dikelola, sementara sebagian besar petani yang berdasa pada kategori usia yang sama memilih untuk mengontrakkan kebun kelapa sawitnya. Petani Arfak yang berada pada usia produktif semua memilih untuk mengontrakkan kebun kelapa sawitnya. Untuk mengetahui faktor penyebab pengambilan keputusan dalam pemilihan model pengelolaan digunakan analisis crosstabultion sebagai. Hasil pengujian hubungan antara faktor tingkat pendidikan terhadap bentuk pengelolaan kebun kelapa sawit pada saat tanaman berusia lebih dari 10 tahun adalah sebagai berikut: 
Tabel 8. Crosstabulation antara Tingkat Pendidikan dan Bentuk Pengelolaan Kebun Kelapa Sawit pada saat Tanaman Berumur lebih dari 10 Tahun

\begin{tabular}{|c|c|c|c|c|c|c|}
\hline \multirow{3}{*}{$\begin{array}{c}\text { Tingkat } \\
\text { Pendidikan }\end{array}$} & \multicolumn{4}{|c|}{ Bentuk Pengelolaan } & \multirow{2}{*}{\multicolumn{2}{|c|}{ Total }} \\
\hline & \multicolumn{2}{|c|}{ Tidak dikelola } & \multicolumn{2}{|c|}{ Kontrak } & & \\
\hline & $\begin{array}{c}\text { Jumlah } \\
\text { (Jiwa) }\end{array}$ & $\begin{array}{c}\text { Nisbah } \\
(\%)\end{array}$ & $\begin{array}{c}\text { Jumlah } \\
\text { (Jiwa) }\end{array}$ & $\begin{array}{c}\text { Nisbah } \\
(\%)\end{array}$ & $\begin{array}{c}\text { Jumlah } \\
\text { (Jiwa) }\end{array}$ & $\begin{array}{c}\text { Nisbah } \\
(\%)\end{array}$ \\
\hline Tidak Sekolah & 10 & 100,00 & 51 & 43,97 & 61 & 48,41 \\
\hline $\mathrm{SD}$ & 0 & 0,00 & 54 & 46,55 & 54 & 42,86 \\
\hline SMP & 0 & 0,00 & 7 & 6,03 & 7 & 5,56 \\
\hline SMA & 0 & 0,00 & 1 & 0,86 & 1 & 0,79 \\
\hline Perguruan Tinggi & 0 & 0,00 & 3 & 2,59 & 3 & 2,38 \\
\hline Total & 10 & 100 & 116 & 100 & 126 & 100 \\
\hline
\end{tabular}

Tabel 8 menunjukkan bahwa hanya sebagian petani yang tidak pernah mengenyam pendidikan yang memilih untuk tidak mengelola kebun kelapa sawitnya yang telah berusia lebih dari 10 tahun, sementara yang lain memilih untuk mengontrakkan kebun kelapa sawitnya. Sebaliknya, semua petani Arfak yang pernah mengenyam pendidikan memilih mengontrakkan kebun kelapa sawitnya. Hal ini disebabkan karena mereka masih membutuhkan pendapatan dari kebun kelapa sawit tanpa harus mengelolanya. Hasil uji signifikansi hubungan disajikan berikut ini:

Tabel 9. Uji Statistik Spearman Faktor-faktor yang mempengaruhi pengambilan keputusan dalam pemilihan usaha kelapa sawit setelah tanaman berumur 10 tahun

\begin{tabular}{lcc}
\hline & Korelasi Spearman & Tingkat signifikansi \\
\hline Usia & $-0,398$ & 0,000 \\
Pendidikan & 0,292 & 0,001 \\
\hline
\end{tabular}

Tabel 9 menunjukkan bahwa nilai signifikansi korelasi spearman antara umur dan model pengelolaan sebesar 0,000, yang berarti umur mempengaruhi pengambilan keputusan untuk mengelola kebun kelapa sawit. Besarnya korelasi sebesar -0,398 menujukkan bahwa korelasinya rendah dan berhubungan negatif, artinya semakin tinggi umur, petani lebih memilih untuk tidak mengelola kebunnya. Hal ini disebabkan karena petani yang masih muda masih mempunya banyak tanggungan untuk memenuhi kebutuhan keluarga, sehingga walaupun mereka tidak mengelola sendiri kebun kelapa sawitnya, mereka tetap masih mengharapkan pendapatan dari kebun kelapa sawitnya, sehingga mereka mengontrakkan kepada petani pengontrak, sedangkan petani yang berusia lanjut, sebagian tinggal dengan anak-anak mereka sehingga kebutuhan mereka dipenuhi oleh anak-anak mereka.

Hasil uji menunjukkan bahwa signifikansi korelasi spearman dari hubungan tingkat pendidikan dan bentuk pengelolaan sebesar 0,001 , yang berarti bahwa hubungan antara tingkat pendidikan dan bentuk pengelolan signifikan. Dengan kata lain pengambilan keputusan terhadap bentuk pengelolaan dipengaruhi oleh tingkat pendidikan. Besarnya korelasi adalah 0,292 yang berarti korelasinya rendah dan positif, artinya semakin tinggi tingkat pendidikan, petani akan cenderung memanfaatkan kebun kelapa sawitnya untuk mendapatkan pendapatan.

Model pengelolaan kontrak lebih banyak dipilih oleh petani Arfak karena sistem ini petani bisa mendapatkan uang sebagai pembayaran sewa/kontrak kebun yang dibayar dimuka. Besarnya sewa kebun berkisar antara 2 sampai 2,5 juta per tahun. Pembayaran sewa/kontrak kebun ini tidak semua dibayar dalam bentuk uang, tetapi dalam bentuk pembangunan rumah. Jangka waktu kontrak ditetapkan berdasarkan persetujuan kedua belah pihak.

\section{KESIMPULAN}

Kesimpulan yang dapat ditarik dari penelitian ini bentuk pengelolaan kebun kelapa sawit yang dipraktekkan oleh petani Arfak di Manokwari mengalami perubahan. Sebelum tanaman kelapa sawit berusia kurang dari 10 tahun, bentuk pengelolaan kebun kelapa sawit adalah kelola sendiri, sewa tenaga kerja dan mengontrakkan kepada petani asal Jawa. Setelah tanaman berusia lebih dari 10 tahun, bentuk pengelolaannya berubah menjadi kontrak dan tidak dikelola. Bentuk 
pengelolaan kebun setelah tanaman berumur lebih dari 10 tahun dipengaruhi oleh meningkatnya umur yang mengakibatkan menurunnya kemampuan fisik untuk bekerja dan berpikir serta tingkat pendidikan petani yang relatif rendah sehingga kurang mampu menolak tawaran pihak lain untukmengeksploitasi kebun kelapa sawitnya.

Berdasarkan hal tersebut, maka diperlukan pendampingan bagi petani Arfak dalam pengambilan keputusan dalam pengelolaan kebun kelapa sawit karena mereka sangat dirugikan ketika mengontrakkan kebun mereka mengingat harga kontrak yang sangat murah. Selain itu, perlunya peningkatan ketrampilan untuk melakukan budidaya kelapa sawit, sehingga petani Arfak mempunyai ketrampilan yang cukup untuk mengelola sendiri kebun kelapa sawitnya.

\section{DAFTAR PUSTAKA}

Undang-Undang RI No No. 20 Tahun 2008 tentang Usaha Mikro, Kecil dan Menengah, (2008).

Christian, A. I., \& Subejo. (2018). Akses, Fungsi, dan Pola Penggunaan Teknologi Informasi dan Komunikasi (TIK) oleh Petani pada Kawasan Pertanian Komersial di Kabupaten Bantul. JSEP, 11(2), 6.

I Made Gannal Dwi Saputra, I G A A Lies Anggreni, \& Dharma, I. P. (2017). Pola Kemitraan Usaha Tani Kelapa Sawit Kelompok Tani Telaga Biru dengan PT. Sawindo Kencana melalui Koperasi di Kabupaten Bangka Barat Provinsi Bangka Belitung. E-Journal of Economics and Policy, 6(2), 9.

Imbiri, S. (2010). Analisis Dampak PIR Kelapa Sawit terhadap Kesejahteraan Masyarakat Sekitar di Kabupaten Manokwari. AGRITEK, 18(2), 15.

Matualage, A. (2011). Keefektifan Pembelajaran Sosial Kearifan Lokal Budidaya Ubi Jalar Di Kalangan Suku Arfak Kabupaten Manokwari. Jurnal Kawistara, 1(1).

Nasution, M. N. F. (2016). Kajian Kemitraan Petani Kelapa Sawit di PT.Agrowiyana Kabupaten Tanjung Jabung Barat, Provinsi Jambi. (Strata 1), Institut Pertanian Bgor, Bogor.

Nauw, M. M. (2007). Petani Papua dan inovasi pertanian : Pengaruh budaya terhadap pola adopsi pertanian PIR Kelapa Sawit; Kasus Petani Suku Arfak di Kabupaten Manokwari Papua (Vol. ). Thesis Jurusan Antropologi Fakultas Ilmu Budaya Universitas Gadjah Mada Tidak diterbitkan.

Obidzinski, K., Dermawan, A., \& Hadianto, A. (2014). Oil palm plantation investments in Indonesia's forest frontiers: limited economic multipliers and uncertain benefits for local communities. Environment. Development and Sustainability Journal, 16(6), 20. doi:10.1007/s10668-014-9519-8

Purnaningsih, N., \& Sugihen, B. G. (2008). Manfaat Keterlibatan Petani Dalam Pola Kemitraan Agribisnis Sayuran Di Jawa Barat. Jurnal Penyuluhan, 4(3), 11.

R.Ratnasari, W.Sarengat, \& A.Setiadi. (2015). Analisis Pendapatan Peternak Ayam Broiler Pada Sistem Kemitraan Di Kecamatan Gunung Pati Kota Semarang. Animal Agriculture Journal, 4(1), 7.

Rochdiani, D., \& Suranta, K. J. (2007). Pola Kemitraan Antara Petani Padi Dengan Pt. E-Farm Bisnis Indonesia Dalam Meningkatkan Pendapatan Petani Padi. Jurnal Sosiohumaniora, Vol. 9, (No. 1$), 6$.

Rudiyanto, A. A. (2014). POLA KEMITRAAN KOPERASI SEJAHTERA ABADI DALAM MENINGKATKAN KEUNTUNGAN PETANI CABAI Journal of Economics and Policy, 7(2), 11. doi:10.15294/jejak.v7i1.3596

Rustiani, F., Sjaifudian, H., \& Gunawan, R. (1997). Mengenal Usaha Pertanian Kontrak (Contract Farming). Bandung: Yayasan AKATIGA.

Subejo, Wati, R. I., Kriska, M., Akhda, N. T., Christian, A. I., Wimatsari, A. D., \& Penggalih, P. M. (2018). Akses, Penggunaan dan Faktor Penentu Pemanfaatan Teknologi Informasi dan Komunikasi pada Kawasan Pertanian Komersial Untuk Mendukung Ketahanan Pangan di Perdesaan. JURNAL KETAHANAN NASIONAL, 24, 17.

Suharno, A.D, Y., \& Barbara, B. (2015). Analisis Kinerja Usahatani Perkebunan Kelapa Sawit Rakyat melalui Pola Kemitraan di Provinsi Kalimantan Tengah. Jurnal Agribisnis Indonesia, 13(2), 10.

Suryana. (2009). Pengembangan Usaha Ternak Sapi Potong Berorientasi Agribisnis Dengan Pola Kemitraan. Jurnal Penelitian dan Pengembangan Pertanian Badan Litbang Pertanian, 28(1).

Turua, U., Hadi, S., Juanda, B., \& Murniningtyas, E. (2014). Ekologi dan Budaya Petani Asli Papua Dalam Usahatani Di Kabupaten Keerom. Jurnal Sosiohumaniora, 16(3), 8.

U.Yuminarti, Darwanto, D. H., Jamhari, \& Subejo. (2018). Contemporary Farming System in the Shifting Cultivation Practiced by Arfak Tribe in Hink District, Pegunungan Arfak Regency, West Papua. Journal Asian Agri-Histrory, 22(6), 10.

Yuminarti, U., Darwanto, D. H., Jamhari, \& Subejo. (2018). Studi Komparasi Praktik Perladangan Berpindah Dan Pertanian Menetap Untuk Mendukung Ketahanan Pangan Masyarakat (Studi Pada Usahatani Kentang di Kabupaten Pegunungan Arfak, Provinsi Papua Barat). JURNAL KETAHANAN NASIONAL, $24,24$. 